\title{
MEMAKSIMALKAN PROLEGNAS DAN PROLEGDA DALAM POLITIK HUKUM NASIONAL (Politik Hukum Penanggulangan Kejahatan Perdagangan Orang di Era Globalisasi)
}

\section{Heni Siswanto}

Dosen Bagian Hukum Pidana Fakultas Hukum Universitas Lampung

\begin{abstract}
Abstrak
Politik pembangunan hukum pemberantasan/pelarangan kejahatan perdagangan orang di era globalisasi melalui pembaharuan sistem hukum pidana (penal system reform) kejahatan perdagangan orang meliputi ruang lingkup yang sangat luas yang mencakup pembaharuan "substansi hukum pidana" meliputi pembaharuan hukum pidana materiel, hukum pidana formal, dan hukum pelaksanaan pidana kejahatan perdagangan orang. Pembaharuan "struktur hukum pidana" meliputi antara lain pembaharuan atau penataan institusi/lembaga, sistem manajemen/ tatalaksana dan mekanismenya serta sarana/prasarana pendukung sistem penegakan hukum pidana (sistem peradilan pidana) kejahatan perdagangan orang; dan pembaharuan "budaya hukum pidana", yang meliputi antara lain masalah kesadaran hukum, perilaku hukum, pendidikan hukum dan ilmu hukum pidana berkaitan dengan kejahatan atau tindak pidana perdagangan orang. Usaha pembaharuan sistem hukum pidana melalui kebijakan kriminal secara integral penanggulangan kejahatan perdagangan orang dengan memasukkan revisi pemberantasan/pelarangan kejahatan perdagangan dalam agenda Prolegnas dan Prolegda 2010-2014, meskipun sekarang ini revisi Undang-Undang Nomor 21 Tahun 2007 tentang Pemberantasan Tindak Pidana Perdagangan Orang belum diagendakan oleh DPR dan Pemerintah. Prolegnas dapat disisipi dengan materi RUU Pemberatasan/Pelarangan Kejahatan Perdagangan Orang, jika ada alasanalasan yang kuat, yaitu karena adanya putusan Mahkamah Konstitusi yang menyebabkan terjadinya kekosongan hukum Pemberatasan/Pelarangan Kejahatan Perdagangan Orang yang harus segera diisi. Ada perjanjian internasional yang harus diratifikasi dalam waktu singkat. Alasan keadaan tertentu lainnya yang memastikan adanya urgensi nasional atas suatu RUU yang dapat disetujui bersama Badan Legislasi DPR dan Kementerian Hukum dan Hak Asasi Manusia.
\end{abstract}

Kata kunci: Globalisasi; Pembaharuan sistem hukum pidana KPO; Revisi UU PTPPO; Prolegnas dan prolegda.

\section{PENDAHULUAN}

Pada era globalisasi sekarang ini, perdagangan orang merupakan persoalan yang menjadi perhatian luas di Asia bahkan di seluruh dunia. Perdagangan orang berubah menjadi kejahatan yang sangat serius yang menarik perhatian masyarakat internasional sebagai kejahatan yang menjadi musuh umat manusia (hostis humanis generis). ${ }^{1} \quad$ Perdagangan

${ }^{1}$ Romli Atmasasmita. 2010. Hukum Pidana Internasional: Dalam Kerangka Perdamaian dan Keamanan Internasional. Fikahati Aneska. Jakarta. Hal. 1. Dalam 
orang terjadi tidak hanya menyangkut di dalam negeri, yaitu perdagangan orang antarpulau, tetapi juga perdagangan orang antarnegara atau disebut kejahatan lintas batas negara/kejahatan transnasional, ${ }^{2}$ baik bersifat perseorangan maupun terorganisasi.

Menurut I Wayan Parthiana ${ }^{3}$
bahwa kejahatan transnasional
menurut sifatnya, dipandang bertentangan dengan hakekat dan martabat kemanusiaan. Oleh karena itu, kejahatan transnasional itu disebut juga sebagai kejahatan yang merupakan musuh umat manusia atau yang lebih dikenal dalam istilah Latin sebagai hostis humanis generis. Sebagai kejahatan transnasional, semua atau bagian terbesar dari negara-negara sangat berkepentingan untuk mencegah, memberantas dan menghukum pelakunya. Oleh karena itu negara-negara di dunia cenderung untuk mencegah dan memberantasnya melalui kerjasama internasional dan mengaturnya melalui konvensi-konvensi internasional.

bukunya yang lain, Romli Atmasasmita. 2003. Pengantar Hukum Pidana Internasional. Refika Aditama. Bandung. Hal. xviii menyatakan bahwa salah satu masalah yang memerlukan perhatian, baik dari masyarakat nasional maupun masyarakat internasional adalah masalah kejahatan lintas batas teritorial. Masalah kejahatan lintas batas teritorial ini terutama pada abad ke-20 sudah dipandang oleh masyarakat internasional sebagai musuh umat manusia (hostis humanis generis). I Wayan Parthiana. 2004. Hukum Pidana Internasional dan Ekstradisi. Yrama Widya. Bandung. Hal. 41 menyebutnya dalam istilah Latin sebagai hostis humani generis.

2 Kejahatan lintas batas negara atau antarnegara menjadi yurisdiksi Konvensi PBB Anti Kejahatan Transnasional Terorganisasi (2000).

${ }^{3}$ I Wayan Parthiana. Op.cit. Hal. 41.
Kejahatan perdagangan orang yang merupakan bagian dari kejahatan terorganisasi, pada dasarnya termasuk salah satu kejahatan terhadap pembangunan dan kejahatan terhadap kesejahteraan sosial yang menjadi pusat perhatian dan keprihatinan nasional dan internasional. Hal itu sangat beralasan, mengingat ruang lingkup dan dimensinya begitu luas, sehingga kegiatannya mengandung ciri-ciri sebagai organized crime, white collar crime, corporate crime dan transnational crime. Bahkan dengan menggunakan sarana teknologi dapat menjadi salah satu bentuk dari cyber crime. ${ }^{4}$ Mengingat perbuatan perdagangan orang yang demikian itu, pada hakikatnya merupakan kejahatan transnasional dan merupakan pelanggaran terhadap harkat dan martabat manusia. Bahkan dalam UNODC dikemukakan bahwa perdagangan orang merupakan suatu kejahatan terhadap kemanusiaan (human trafficking is a crime against humanity). ${ }^{5}$

Usaha-usaha masyarakat internasional dalam mencegah dan memberantas kejahatan-kejahatan transnasional dapat dilakukan dengan kerjasama secara fisik maupun dengan menuangkan pengaturannya dalam konvensi internasional. ${ }^{6}$ Berbagai konvensi tentang penghapusan perbudakan seperti Slavery Convention Tahun 1926 yang ditambah dan diperbaharui pada tahun 1953 disempurnakan lagi pada

${ }^{4}$ M. Arief Amrullah. 2009. Politik Hukum Pidana Perlindungan Korban Tindak Pidana Perdagangan Orang. Dalam Memahami Hukum: Dari Konstruksi sampai Implementasi. editor, Satya Arinanto dan Ninuk Triyanti. Rajawali. Jakarta. Hal. 121.

${ }^{5}$ Ibid. Hal. 123.

${ }^{6}$ Loc. Cit. I Wayan Parthiana. Hal. 42. 
tahun 1956 atas inisiatif ECOSOC. Berdasarkan konvensi ini para pihak sepakat akan menyusun perundangundangan nasional yang efektif serta akan melakukan tindakan-tindakan demi menghapus praktek-praktek perbudakan atau yang berhubungan dengan itu seperti utang perbudakan, jual-beli manusia (perdagangan orang, pen.) eksploitasi tenaga anakanak dan penjualan budak-budak antarnegara. Para pelakunya harus diadili dan dihukum dengan hukuman berat. ${ }^{7}$ Pada tahun 1984 Pemerintah RI juga telah meratifikasi Konvensi mengenai Penghapusan Segala Bentuk Diskriminasi terhadap Wanita (disingkat Konvensi Wanita) melalui Undang-Undang Nomor 7 Tahun 1984. Sepuluh tahun kemudian pada tahun 1994, pada umumnya masyarakat belum juga mengetahui akan keberadaan Konvensi Wanita. ${ }^{8}$

\section{Perdagangan}

orang

(trafficking) merupakan bentuk modern dari perbudakan manusia dan merupakan bentuk terburuk dari pelanggaran hak asasi manusia yang telah meluas, baik di dalam negeri maupun antarnegara. Tindak pidana atau kejahatan perdagangan orang (TPPO) sebagai salah satu bentuk kekerasan dan merupakan pelanggaran berat hak asasi manusia, sangat bertentangan dengan harkat dan martabat manusia serta berdampak psikologis pada korban maupun keluarganya yang umumnya cukup berat dan membutuhkan penanganan dari para profesional,

${ }^{7}$ Ibid. Hal. 44.

${ }^{8}$ L.M. Gandhi Lapian. 2010. Convention Watch UI: Kiprah Penanggulangan Trafiking di Sulawesi Utara. Dalam Trafiking Perempuan dan Anak: Penanggulangan Komprehensif Studi Kasus: Sulawesi Utara. Yayasan Obor Indonesia. Hal. 1. baik di bidang kesehatan, psikologi, maupun hukum. ${ }^{9}$

Bentuk-bentuk terburuk dari trafficking atau diistilahkan lain dengan human trafficking/trafficking in woman and child/trafficking in persons/trafiking/ perdagangan orang, baik terjadi di luar negeri maupun di Indonesia sendiri, antara lain: kerja paksa seks dan eksploitasi seksual, pembantu rumah tangga (PRT), buruh migran, penari, penghibur dan pertukaran budaya, pengantin pesanan (mail order bride), buruh/pekerja anak, serta penjualan bayi. Sebagai bentuk kasus yang kompleks dan rumit, modus operandi tindak pidana trafficking berkembang seiring semakin canggihnya akses ilegal yang tersembunyi dengan rapi, sehingga membentuk jaringan luas, baik secara lokal, regional maupun global. Tak dipungkiri pula bahwa masih terpeliharanya faktor-faktor lain penyebab terjadinya trafficking, terutama di daerah-daerah terpencil seperti kurangnya kesadaran, kemiskinan, faktor budaya, lemahnya peran perempuan dan anak perempuan dalam keluarga, perkawinan dini, jeratan hutang, kurangnya kesadaran tentang pencatatan kelahiran, rendahnya tingkat pendidikan, serta masih banyaknya korupsi dan lemahnya penegakan hukum makin menguatkan akar-akar penyebab terjadinya trafficking. ${ }^{10}$

\footnotetext{
${ }^{9}$ http://www.menegpp.go.id/index.php?optio $\mathrm{n}=\mathrm{com} \_$content $\&$ view=article\&id=282:rakor nas-evaluasi-gugus-tugas-pencegahan-danpenanganan-tppo-2010\&catid=36: pressrelease $\&$ Itemid $=87$ diunduh pada tanggal 17 Mei 2011 pukul 20.31 wib.

${ }^{10}$ http://www.menegpp.go.id/index.php?opti on=com_content $\&$ view $=$ article $\&$ id $=147$ :jam eela-a-sang-presiden \&catid=38:artikel-
} 
$\begin{array}{cc}\text { Menurut Nur Iman Subono, } & { }^{11} \\ \text { perdagangan } & \text { orang }\end{array}$ trafficking) juga menjadi issue yang sangat krusial di dunia politik tahun 1990-an. Pihak-pihak yang sangat concern dengan issue ini, khususnya di kalangan feminis dan organisasi hak asasi manusia, mengungkapkan bahwa perdagangan orang, khususnya sex trafficking, yakni perempuan dan gadis yang dipaksa untuk bermigrasi dan bekerja sebagai PSK (pekerja seks komersial) di dunia pelacuran, meningkat sebagai masalah internasional yang merupakan bentuk dari "perbudakan modern" (modern day slavery) yang sangat memerlukan perhatian dan tindakan internasional.

Farhana $^{12}$ mengungkapkan Laporan Survei Dunia IV tentang Perempuan dan Pembangunan (1999) menyebutkan bahwa banyak negara berkembang di Asia seperti Vietnam, Srilangka, Thailand, dan Filipina mengalami persoalan yang sama (dengan Indonesia, pen.) mengenai perdagangan orang, sebagai akibat dari ketidakpastian dan ketidakmampuan menghadapi persaingan bebas dari konsep liberalisme ekonomi di era globalisasi yang mempunyai dampak kompleks terutama terhadap peran dan kedudukan perempuan dalam bidang ekonomi, baik di tingkat nasional maupun internasional. Oleh karena itu, perdagangan orang juga terkait

perempuan\&Itemid=114 diunduh pada tanggal 17 Mei 2011 pukul 20.33 wib.

${ }^{11}$ Nur Iman Subono. 2010. "Trafficking in Human Beings dalam Angka dan Perdebatan" dalam Jurnal Perempuan: Untuk pencerahan dan kesetaraan 68 . Trafficking dan Kebijakan. Yayasan Jurnal Perempuan. Hal. 21.

${ }^{12}$ Farhana. 2010. Aspek Hukum Perdagangan Orang di Indonesia. Sinar Grafika. Jakarta. Hal. 5. erat dengan kejahatan transnasional yang merendahkan martabat bangsa dan negara dengan memperlakukan korban semata sebagai komoditi yang bisa dibeli, dijual, dikirim, dan dijual kembali.

Perkembangan kejahatan ini semakin mengkhawatirkan yang ditunjukkan dengan meningkatnya kuantitas dan kualitas kejahatan yang mayoritas korbannya perempuan dan anak. Undang-Undang Nomor 21 Tahun 2007 tentang Pemberantasan Tindak Pidana Perdagangan Orang (UU PTPPO) telah berlaku selama 4 (empat) tahun, akan tetapi penegakan hukum dengan menggunakan sarana penal belum menunjukkan tandatanda keberhasilan. Penyusunan UU PTPPO itu juga merupakan perwujudan komitmen Indonesia untuk melaksanakan Protokol PBB Tahun 2000 tentang Mencegah, Memberantas dan Menghukum Tindak Pidana Perdagangan Orang, khususnya Perempuan dan Anak (Protokol Palermo) yang telah ditandatangani Indonesia.

Kebijakan kriminal yang ditempuh Pemerintah dalam usaha penanggulangan kejahatan perdagangan orang dilakukan dengan menggunakan sarana secara penal dan nonpenal. Upaya pemberantasan kejahatan ini dengan menggunakan alat/sarana secara penal melalui penegakan hukum kejahatan perdagangan orang secara represif ${ }^{13}$

13 Barda Nawawi Arief mengatakan upaya penanggulangan kejahatan secara garis besar dapat dibagi dua, yaitu lewat jalur "penal" (hukum pidana) dan lewat jalur "nonpenal" (bukan/diluar hukum pidana). Dalam pembagian G.P. Hoefnagels di atas, upayaupaya yang disebut dalam butir (b) dan (c) dapat dimasukkan dalam kelompok upaya "nonpenal". Secara kasar dapatlah dibedakan, bahwa upaya penanggulangan kejahatan lewat jalur "penal" lebih 
dengan menerapkan Pasal 2 sampai dengan Pasal 18 UU PTPPO, sebagian di antaranya mengancam pelaku perdagangan orang dengan pidana penjara paling singkat 3 (tiga) tahun dan paling lama 15 (lima belas) tahun dan pidana denda paling sedikit Rp.120.000.000,00 (seratus dua puluh juta rupiah) dan paling banyak Rp. 600.000.000,00 (enam ratus juta rupiah). Sementara kebijakan kriminal terhadap kejahatan perdagangan orang yang ditempuh oleh pembentuk undangundang dengan menggunakan sarana nonpenal diatur dalam Bab VI perihal Pencegahan dan Penanganan UU TPPO dalam Pasal 56 sampai dengan Pasal 58 UU PTPPO.

Kebijakan penegakan hukum pidana setelah berakhirnya tahap kebijakan legislatif/formulatif, memasuki tahap kebijakan yudikatif/ aplikatif dan tahap kebijakan eksekutif/administratif. ${ }^{14}$ Ketiga tahap kebijakan penegakan hukum pidana itu terkandung di dalamnya tiga kekuasaan/kewenangan, oleh karena itu kekuasaan legislatif/ formulatif terkait dengan menetapkan atau merumuskan perbuatan apa yang dapat dipidana dan saksi apa

menitikberatkan pada sifat "repressive" (penindasan/pemberantasan/penumpasan) sesudah kejahatan terjadi, sedangkan jalur "nonpenal" lebih menitikberatkan pada sifat "preventive" (pencegahan/penangkalan/ pengendalian) sebelum kejahatan terjadi. Dikatakan sebagai pembedaan secara kasar, karena tindakan represif pada hakikatnya juga dapat dilihat sebagai tindakan preventif dalam arti luas. Dalam, Barda Nawawi Arief. Bunga Rampai Kebijakan Hukum Pidana Perkembangan Penyusunan Konsep KUHP Baru. Kencana. Jakarta. 2010. Hal. 42.

14 Barda Nawawi Arief. Beberapa Aspek Kebijakan Penegakan dan Pengembangan Hukum Pidana. Edisi Revisi. Citra Aditya Bakti. Bandung. 2005. Hal. 30. yang dapat dikenakan; kekuasaan yudikatif/aplikatif terkait dengan penerapan hukum pidana; dan kekuasaan eksekutif/administratif terkait dengan melaksanakan hukum pidana.

Di antara dua pilihan sarana penanggulangan kejahatan itu, pilihan penegakan hukum yang ditempuh oleh pemegang kekuasaan di tahap kebijakan yudikatif dan kebijakan eksekutif lebih mengutamakan penggunaan sarana penal yang lebih menitikberatkan pada sifat repressive (penindasan/ pemberantasan/penumpasan) sesudah kejahatan terjadi dalam penegakan hukum pemberantasan tindak pidana perdagangan orang daripada menggunakan sarana nonpenal yang lebih menitikberatkan pada sifat preventive (pencegahan/penangkalan /pengendalian) sebelum kejahatan terjadi, ${ }^{15}$ yang ditujukan pada penghapusan sebab-sebab dan kondisi-kondisi yang menimbulkan kejahatan (based upon the elimination of causes and conditions giving rise to crime) dan penyebab utama dari kejahatan di banyak negara ialah ketimpangan sosial, diskriminasi rasial dan diskriminasi nasional, standar hidup yang rendah, pengangguran dan kebutahurufan (kebodohan) di antara golongan besar penduduk (the main causes of crime in many countries are social inequality, racial and national discrimination, low standard of living, unemployment and illiteracy among broad sections of the population). ${ }^{16}$

15 Barda Nawawi Arief. Bunga Rampai Kebijakan Hukum Pidana Perkembangan Penyusunan Konsep KUHP Baru. Kencana. Jakarta. 2010. Hal. 42.

16 Sixth United Nations Congress. Report. 1981. Hal. 5 dalam Barda Nawawi Arief. 
Upaya penanggulangan kejahatan perdagangan orang dengan menggunakan sarana tunggal, yaitu penal yang ditempuh dan menjadi kebijakan pemerintah selama ini belum memperlihatkan keberhasilannya selama 4 (empat) tahun terakhir ini. Data atau angka-angka statistik kejahatan perdagangan orang menunjukkan trend bukannya semakin bisa diberantas/ditekan/ ditanggulangi/ dikurangi, sebaliknya memperlihatkan angka-angka yang semakin meningkat jumlahnya. Keadaan ini dapat dinyatakan bahwa upaya penanggulangan kejahatan perdagangan orang dengan menggunakan sarana penal memiliki keterbatasan dalam penegakan hukum secara represif. Penggunaan pidana/penal belum bisa dinyatakan efektif untuk mencegah, menekan, memberantas atau menanggulangi kejahatan perdagangan orang.

Kasus kejahatan TPPO dari tahun ke tahun semakin meningkat. Pengiriman tenaga kerja Indonesia ke luar negeri sering dijadikan modus kejahatan TPPO. Para korban TPPO ini biasanya masuk lewat jalur ilegal melalui para calo. Setiap tahun sedikitnya 450.000 warga Indonesia, $70 \%$ di antaranya adalah perempuan yang diberangkatkan sebagai tenaga kerja ke luar negeri. Dari jumlah tersebut, sekitar $46 \%$ terindikasi kuat menjadi korban TPPO (Migrant Care, 2009). ${ }^{17}$

Bunga Rampai Kebijakan Hukum Pidana Perkembangan Penyusunan Konsep KUHP Baru. Kencana. Jakarta. 2010. Hal. 43. ${ }^{17}$ Ibid.

http://www.menegpp.go.id/index.php?option $=$ com_content $\&$ view $=$ article $\& i d=326:$ mene g-pp-a-pa-berbincang-santai-dengan-menkokesra-menkes-dan-mendiknas-seusai-rakorbidang-kesra\&catid=36:press-

release \&Itemid $=87$ diunduh pada tanggal 17 Mei 2011 pukul 20.29 wib.
Data yang dikeluarkan oleh Pusat Informasi dan Komunikasi Departemen Hukum dan HAM RI, juga menunjukkan angka yang sangat memprihatinkan terhadap tindak pidana trafficking. Berdasarkan jenis kelamin, korban trafficking didominasi kaum perempuan, yaitu sebanyak $89,7 \%$. Sedangkan data berdasarkan umur, korban trafficking dewasa sebanyak: 74,77\%; anakanak $25,08 \%$ dan balita sebanyak $0,15 \%{ }^{18}$ Demikian pula data Bareskrim Mabes Polri Tahun 2009 yang telah dimuat dalam Jurnal Perempuan 68, 2010 (dikutip Emmy LS) dalam tabel di bawah ini. ${ }^{19}$

Berdasarkan paparan di atas menunjukkan bahwa upaya penanggulangan kejahatan dengan menggunakan sarana penal melalui penegakan hukum yang bersifat represif dengan menerapkan Undang-Undang Nomor 21 Tahun 2007 tentang Pemberantasan Tindak Pidana Perdagangan Orang (UU PTPPO) dan peraturan pelaksanaan lainnya dipandang belum efektif mencapai keberhasilan dengan menekan angka kejahatan perdagangan orang.

Upaya untuk mencegah dan menanggulangi kejahatan perdagangan orang yang semakin mengglobal dan meningkat kualitas dan kuantitasnya itu sangat mendesak untuk dilakukan

\footnotetext{
${ }^{18}$ Op.Cit.http://www.menegpp.go.id/index.p $\mathrm{hp}$ ?option=com_content $\&$ view=article $\&$ id $=$ 147:jameela-a-sangpresiden\&catid=38: artikelperempuan\&Itemid=114 diunduh pada tanggal 17 Mei 2011 pukul 20.33 wib.

${ }^{19}$ Emmy L.S. 2010. Makalah "Implementasi UU PTPPO bagi Anak Korban Perdagangan," dalam Jurnal Perempuan: Untuk pencerahan dan kesetaraan 68. Trafficking dan Kebijakan. Yayasan Jurnal Perempuan. Jakarta.
} 
pembaharuan pembentukan hukum nasional dalam kerangka kebijakan kriminal secara integral sebagai upaya penanggulangan kejahatan perdagangan orang yang lebih efektif untuk mencegah, menangani, menekan, memberantas dan menanggulangi kejahatan perdagangan orang melalui politik hukum penanggulangan kejahatan perdagangan orang dengan kebijakan integral yang menggunakan dua sarana penanggulangan kejahatan perdagangan orang secara sekaligus, yaitu penggunaan sarana penal dan nonpenal dalam memerangi laju kejahatan perdagangan orang melalui prolegnas dan prolegda di seluruh wilayah Republik Indonesia.

Dengan demikian, maka Bagaimanakah politik hukum pemberantasan kejahatan perdagangan orang di era globalisasi? Dan Bagaimanakah memasukkan pembaharuan perundang-undangan pemberantasan kejahatan perdagangan orang yang tidak diagendakan dalam Prolegnas dan Prolegda 2010-2014?

Tabel 1

Rekapitulasi Data Penanganan TPPO Tahun 2004-2009

\begin{tabular}{|l|c|c|c|c|c|c|}
\hline NO & TAHUN & $\begin{array}{c}\text { JUMLAH } \\
\text { KORBAN } \\
\text { DEWASA }\end{array}$ & $\begin{array}{c}\text { JUMLAH } \\
\text { KORBAN } \\
\text { ANAK }\end{array}$ & $\begin{array}{c}\% \\
\text { KORBAN } \\
\text { ANAK }\end{array}$ & $\begin{array}{c}\text { JUMLAH } \\
\text { KASUS }\end{array}$ & PROSES \\
\hline 1 & 2004 & 103 & 10 & $9 \%$ & 76 & $45: \mathrm{P} 21$ \\
\hline 2 & 2005 & 125 & 18 & $13 \%$ & 71 & $40: \mathrm{P} 21$ \\
\hline 3 & 2006 & 486 & 129 & $21 \%$ & 84 & $57: \mathrm{P} 21$ \\
\hline 4 & 2007 & 334 & 240 & $42 \%$ & 177 & $88: \mathrm{P} 21$ \\
\hline 5 & 2008 & 519 & 88 & $15 \%$ & 199 & $107: \mathrm{P} 21$ \\
\hline 6 & 2009 & 145 & 53 & $27 \%$ & 102 & $41: \mathrm{P} 21$ \\
\hline
\end{tabular}

Sumber: Data Bareskrim Mabes Polri Tahun 2009, dimuat dalam Jurnal Perempuan 68 tahun 2010.

\section{PEMBAHASAN}

\subsection{Politik Hukum \\ Pembangunan Hukum \\ Pemberantasan Kejahatan \\ Perdagangan Orang Di Era \\ Globalisasi}

Secara etimologi, politik hukum merupakan terjemahan dari istilah hukum Belanda rechtspolitiek yang merupakan bentukan dari dua kata recht dan politiek. $^{20}$ Moh.

${ }^{20}$ Sri Soemantri. 2001. "Undang-Undang Dasar 1945, Kedudukan dan Artinya dalam Kehidupan Bernegara". Jurnal Demokrasi
Mahfud MD merumuskannya sebagai arahan atau garis resmi yang dijadikan dasar berpijak dan cara untuk membuat dan melaksanakan hukum dalam rangka mencapai tujuan bangsa dan negara. ${ }^{21}$ Imam Syaukani dan A. Ahsin Thohari menyebutkan politik hukum sebagai kebijakan dasar penyelenggara

dan HAM: Vol 1 No. 4 SeptemberNovember 2001. Dikutip Imam Syaukani dan A. Ahsin Thohari. 2010. Dasar-dasar Politik Hukum. Rajawali Pers. Jakarta. Hal. 19.

${ }^{21}$ Moh. Mahfud MD. 2010. Membangun Politik Hukum, Menegakkan Konstitusi. Rajawali Pers. Jakarta. Hal. 15. 
negara dalam bidang hukum yang akan, sedang dan telah berlaku, yang bersumber dari nilai-nilai yang berlaku di masyarakat untuk mencapai tujuan negara yang dicitacitakan. $^{22}$

$$
\text { Moh. Mahfud } \text { MD }^{23}
$$
menjelaskan bahwa politik hukum adalah legal policy ${ }^{24}$ atau garis (kebijakan) resmi tentang hukum yang akan diberlakukan, baik dengan pembuatan hukum baru maupun dengan penggantian hukum lama, dalam rangka mencapai tujuan negara. Dengan demikian politik hukum merupakan pilihan tentang hukum-hukum yang akan diberlakukan sekaligus pilihan tentang hukumhukum yang akan dicabut atau tidak diberlakukan yang kesemuanya dimaksudkan untuk mencapai tujuan negara seperti yang tercantum di dalam Pembukaan UUD 1945. Di sini hukum diposisikan sebagai alat untuk mencapai tujuan negara. Terkait dengan ini Sunaryati Hartono pernah mengemukakan bahwa "hukum sebagai alat", sehingga secara praktis politik hukum juga merupakan alat atau sarana dan langkah yang dapat digunakan oleh pemerintah untuk menciptakan sistem hukum nasional guna mencapai cita-cita bangsa dan tujuan

${ }^{22}$ Ibid. Imam Syaukani dan A. Ahsin Thohari. Hal. 32.

${ }^{23}$ Moh. Mahfud MD. 2010. Politik Hukum di Indonesia. Rajawali Pers. Jakarta. Hal. 1 .

${ }^{24}$ Muladi. 2002. Demokratisasi, Hak Asasi Manusia, dan Reformasi Hukum di Indonesia. The Habibie Center. Jakarta. Hal. 259 menegaskan bahwa "hukum" dan "politik hukum" (legal policy) pada dasrnya merupakan produk dari sistem politik. Dengan demikian nampak bahwa warna dan kualitas hukum yang berlaku dalam masyarakat akan tergantung pada warna dan kualitas sistem politik yang berlaku. negara. $^{25}$ Dengan demikian, politik hukum (legal policy) ${ }^{26}$ pemberantasan kejahatan perdagangan orang yang telah diberlakukan, baik dengan pembuatan hukum baru maupun dengan penggantian hukum lama, tentunya dalam rangka untuk mencapai tujuan negara. Hukum pemberantasan kejahatan perdagangan orang dipandang sebagai alat, sehingga secara praktis politik hukum ini juga merupakan alat atau sarana dan langkah yang dapat digunakan oleh pemerintah untuk menciptakan sistem hukum nasional guna mencapai cita-cita bangsa dan tujuan negara, karena politik hukum merupakan pilihan tentang hukum-hukum yang akan diberlakukan sekaligus pilihan tentang hukum-hukum yang akan dicabut atau tidak diberlakukan berkaitan dengan pemberantasan kejahatan perdagangan orang yang kesemuanya dimaksudkan untuk mencapai tujuan negara seperti yang tercantum di dalam Pembukaan UUD 1945.

Pembuatan hukum baru maupun penggantian hukum lama, dalam rangka untuk mencapai tujuan negara identik dengan pembaharuan hukum nasional dalam kerangka kebijakan kriminal secara integral sebagai upaya penanggulangan

${ }^{25}$ C.F.G. Sunaryati Hartono. 1991. Politik Hukum Manuju Satu Sistem Hukum Nasional. Alumni. Bandung. Hlm. 1.

${ }^{26}$ Loc.cit. Muladi. Hal. 269 menyatakan bahwa politik hukum (legal policy) dalam arti kebijakan negara (public policy) di bidang hukum harus dipahami sebagai bagian kebijakan sosial, yaitu usaha setiap masyarakat/pemerintah untuk meningkatkan kesejahteraan warganya di segala aspek kehidupan. Hal ini bisa mengandung dua dimensi yang terkait satu sama lain, yaitu kebijakan kesejahteraan sosial (social welfare state) dan kebijakan perlindungan sosial (social defence policy). 
kejahatan perdagangan orang yang lebih efektif untuk mencegah, menangani, menekan, memberantas dan menanggulangi kejahatan perdagangan orang melalui politik hukum penanggulangan kejahatan perdagangan orang dengan kebijakan integral yang menggunakan dua sarana penanggulangan kejahatan TPPO secara sekaligus, yaitu penggunaan sarana penal dan sarana nonpenal dalam memerangi laju kejahatan TPPO.

Penanggulangan kejahatan dengan menggunakan hukum pidana tercermin di dalam Undang-Undang Nomor 21 Tahun 2007 tentang Pemberantasan Tindak Pidana Perdagangan Orang (UU PTPPO). Kebijakan penanggulangan kejahatan perdagangan orang dalam UU PTPPO dapat dilihat mulai dari konsiderannya (menimbang) bahwa perdagangan orang, khususnya perempuan dan anak, merupakan tindakan yang bertentangan dengan harkat dan martabat manusia dan melanggar hak asasi manusia, sehingga harus diberantas. Sementara perdagangan orang telah meluas dalam bentuk jaringan kejahatan yang terorganisasi dan tidak terorganisasi, baik bersifat antarnegara maupun dalam negeri, sehingga menjadi ancaman terhadap masyarakat, bangsa, dan negara, serta terhadap norma-norma kehidupan yang dilandasi penghormatan terhadap hak asasi manusia.

Dengan kondisi kejahatan perdagangan orang demikian itu, maka wajarlah ada keinginan untuk mencegah dan menanggulangi tindak pidana perdagangan orang yang didasarkan pada nilai-nilai luhur, komitmen nasional, dan internasional untuk melakukan upaya pencegahan sejak dini, penindakan terhadap pelaku, perlindungan korban, dan peningkatan kerja sama, yang didasarkan atas peraturan perundangundangan yang berkaitan dengan perdagangan orang yang memberikan landasan hukum yang menyeluruh dan terpadu bagi upaya pemberantasan tindak pidana perdagangan orang. ${ }^{27}$

Dalam kebijakan legislasi UU PTPPO sejumlah pasal telah mengatur mengenai semua "perencanaan" (planning) penanggulangan kejahatan perdagangan orang dengan sistem hukum pidana yang meliputi pembangunan-pembangunan

substansi hukum, struktur hukum dan budaya hukum dalam kerangka pemberantasan, penanganan, dan penanggulangan kejahatan perdagangan orang. Dan, penanggulangan kejahatan perdagangan orang dengan sistem non-hukum pidana yang meliputi pembangunan substansi hukum, struktur hukum, budaya hukum dan pembangunan sarana serta prasarana dalam kerangka pencegahan dilakukannya kejahatan perdagangan orang.

Keseluruhan sistem hukum pidana yang dirancang itu, pada intinya mencakup tiga masalah pokok dalam hukum pidana, yaitu masalah perumusan tindak pidana (kriminalisasi), pertanggungjawaban pidana, dan aturan pidana dan pemidanaan ${ }^{28}$ kejahatan perdagangan orang yang diatur di dalam sejumlah pasal, di antaranya terkait dengan kebijakan kriminal yang menggunakan sarana penal, khususnya terkait dengan perumusan tindak

27 Konsideran Undang-Undang Nomor 21 Tahun 2007 tentang Pemberantasan Tindak Pidana Perdagangan Orang (UU PTPPO).

${ }^{28}$ Loc.cit. Hal. 215. 
pidana dan aturan pidana dan pemidanaan dalam UU No. 21 Tahun 2007, yaitu Pasal 12 sampai dengan Pasal 18.

Adapun kebijakan kriminal dengan menggunakan sarana nonpenal juga telah diatur dalam Bab VI UU TPPO, yaitu 56-57.

Pasal 56 Pencegahan tindak pidana perdagangan orang bertujuan mencegah sedini mungkin terjadinya tindak pidana perdagangan orang.

\section{Pasal 57}

(1) Pemerintah, Pemerintah Daerah, masyarakat, dan keluarga wajib mencegah terjadinya tindak pidana perdagangan orang.

(2) Pemerintah dan Pemerintah Daerah wajib membuat

kebijakan, program, kegiatan, dan mengalokasikan anggaran untuk melaksanakan pencegahan dan penanganan masalah perdagangan orang (ditebalkan, pen.).

\section{Pembangunan UU PTPPO} merupakan ketentuan peraturan perundang-undangan baru yang dibentuk untuk menjawab semakin meningkatnya angka kejahatan dan sifat berbahayanya kejahatan perdagangan orang yang telah berkembang menjadi kejahatan lintas batas yang terorganisasi atau transnational organized crime (TOC) di era globalisasi ini. Kejahatan perdagangan orang sebagai bentuk modern dari perbudakan manusia juga merupakan salah satu bentuk perlakuan terburuk dari pelanggaran harkat dan martabat manusia yang harus dilindungi hak asasi manusianya.

Pembentukan UU PTPPO ditujukan untuk mengantisipasi dan menjerat semua jenis tindakan dalam proses, cara, atau semua bentuk eksploitasi yang mungkin terjadi dalam praktik perdagangan orang, baik yang dilakukan antarwilayah dalam negeri maupun secara antarnegara, dan baik oleh pelaku perorangan maupun korporasi. UU PTPPO juga mengatur perlindungan saksi dan korban sebagai aspek penting dalam penegakan hukum, yang dimaksudkan untuk memberikan perlindungan dasar kepada korban dan saksi. Selain itu, UU PTPPO juga memberikan perhatian yang besar terhadap penderitaan korban sebagai akibat tindak pidana perdagangan orang dalam bentuk hak restitusi yang harus diberikan oleh pelaku tindak pidana perdagangan orang sebagai ganti kerugian bagi korban, dan mengatur juga hak korban atas rehabilitasi medis dan sosial, pemulangan serta reintegrasi yang harus dilakukan oleh negara khususnya bagi mereka yang mengalami penderitaan fisik, psikis, dan sosial akibat tindak pidana perdagangan orang. ${ }^{29}$

Berikut ini dikemukakan penanggulangan kejahatan perdagangan orang dengan menggunakan hukum pidana dengan bentuk sanksinya berupa pidana penjara ataupun pidana denda dipandang memiliki batas-batas kemampuan dalam penanggulangan kejahatan perdagangan orang.

Barda Nawawi Arief menyatakan bahwa upaya penanggulangan kejahatan dengan menggunakan sanksi (hukum) pidana merupakan cara yang paling tua, setua peradaban manusia itu sendiri. Sampai saat ini pun, hukum pidana masih digunakan dan "diandalkan"

29 Op.cit. Penjelasan Undang-Undang Nomor 21 Tahun 2007 tentang Pemberantasan Tindak Pidana Perdagangan Orang (UU PTPPO). 
sebagai salah satu sarana politik kriminal. Bahkan, akhir-akhir ini, pada bagian akhir kebanyakan produk perundang-undangan hampir selalu dicantumkan subbab tentang "ketentuan pidana". Hal ini terlihat bahwa hukum pidana hampir selalu dipanggil untuk "menakut-nakuti atau mengamankan" bermacammacam kejahatan yang mungkin timbul di berbagai bidang. Fenomena atau kebijakan praktek legislatif yang demikian memberi kesan, seolaholah dirasakan kurang sempurna atau "hambar" apabila suatu produk perundang-undangan tidak ada ketentuan pidananya. Fenomena legislatif yang demikian menarik untuk dikaji dari sudut kebijakan hukum pidana (penal policy), khususnya dilihat dari batas-batas kemampuan hukum pidana sebagai sarana penanggulangan kejahatan. ${ }^{30}$

Kebijakan Pemerintah memilih kebijakan kriminal dengan menggunakan sarana penal dalam upaya penanggulangan kejahatan perdagangan orang pada tahap kebijakan formulasi dan tahap kebijakan implementasi yang ditempuh Pemerintah RI melalui pembentukan dan pelaksanaan UU PTPPO cenderung mengutamakan arus pembentukan pada aspek substansi hukum pidana dan aspek struktur hukum pidana dengan mengabaikan pembangunan budaya hukum masyarakat Indonesia. Padahal yang sesungguhnya sikap masyarakat bisa menjadi pendukung utama berlaku efektifnya suatu

30 Barda Nawawi Arief, Batas-batas Kemampuan Hukum Pidana dalam Penanggulangan Kejahatan, dalam Beberapa Aspek Kebijakan Penegakan dan Pengembangan Hukum Pidana, Edisi Revisi, Citra Aditya Bakti, Jakarta, 2005, hal. 67-68. peraturan yang dibuat oleh Pemerintah dan DPR RI. Budaya hukum masyarakat dalam bentuk kesadaran hukum dan perilaku yang patuh yang sangat mendukung berlakunya hukum pidana yang melarang dilakukannya kejahatan perdagangan orang dan partisipasi aktif masyarakat dalam penegakan hukum yang efektif.

Kebijakan pembaharuan dan pelaksanaan UU PTPPO yang mengabaikan pembangunan budaya hukum melalui penggunaan sarana nonpenal dapat dikategorikan sebagai kebijakan inkremental atau sering dikatakan sebagai kebijakan kecil-kecilan atau tambal sulam atau lebih bersifat meneruskan kebijakan formulasi dan kebijakan implementasi sejumlah perundangundangan yang ada sebelumnya yang berkaitan dengan larangan dilakukannya kejahatan perdagangan orang.

Melalui prolegnas dan prolegda di seluruh Indonesia, terutama di daerah sumber atau pengirim perdagangan orang lebih ditekankan pada upaya penanggulangan kejahatan perdagangan orang secara nonpenal yang nantinya diharapkan mampu menghapuskan dan menghilangkan penyebab-penyebab dan kondisi-kondisi yang menimbulkan kejahatan perdagangan orang.

Menurut Barda Nawawi Arief ${ }^{31}$ upaya pembaharuan hukum secara umum di Indonesia sebenarnya sudah

\footnotetext{
${ }^{31}$ Barda Nawawi Arief. 2005. Beberapa Aspek Pengembangan Ilmu Hukum Pidana (Menyongsong Generasi Baru Hukum Pidana Indonesia) Pidato Pengukuhan sebagai Guru Besar Ilmu Hukum di hadapan Rapat Senat Terbuka Undip, Semarang 25 Juni 1994 hal. 1, juga dimuat di Beberapa Aspek Kebijakan Penegakan dan Pengembangan Hukum Pidana. Citra Aditya Bakti. Bandung. Hal. 121.
} 
dimulai sejak lahirnya UUD 1945, tentu tidak dapat dilepaskan pula dari landasan sekaligus tujuan yang ingin dicapai oleh bangsa Indonesia seperti telah dirumuskan dalam Pembukaan UUD 1945 yaitu "melindungi segenap bangsa Indonesia dan untuk mewujudkan kesejahteraan umum berdasarkan Pancasila". Sementara menurut Satjipto Rahardjo ${ }^{32}$ Pembangunan hukum pada era globalisasi akan mempunyai arti khusus untuk pembangunan bidang hukum, karena bermakna bahwa hukum Indonesia akan menuju pada keterbukaan yang lebih besar pada nilai-nilai dan tatanan norma yang berlaku pada hukum internasional (publik dan perdata).

Pembaharuan hukum pidana (law reform) kejahatan perdagangan orang ini untuk memerangi, menanggulangi dan memberantas kejahatan transnasional tindak pidana perdagangan orang tentunya dengan jalan pembaharuan hukum melalui kebijakan integral penanggulangan kejahatan perdagangan orang di era globalisasi. Rekonstruksi kebijakan integral ini harus dilakukan dalam skema politik kriminal $^{33}$ yang diintegrasikan dengan keseluruhan kebijakan sosial dan perencanaan pembangunan (nasional) sebagai upaya perlindungan masyarakat (social defence) dan upaya mencapai kesejahteraan masyarakat (social welfare), yaitu perlindungan masyarakat untuk mencapai

\footnotetext{
${ }^{32}$ Satjipto Rahardjo. 2009. Membangun dan Merombak Hukum Indonesia: Sebuah Pendekatan Lintas Disiplin. Genta Publishing. Yogyakarta. Hal. xiii.

${ }^{33}$ Is. Heru Permana. 2007. Politik Kriminal. Universitas Atma Jaya. Yogyakarta. Hal. 9 menyatakan bahwa kebijakan kriminal adalah usaha rasional dan terorganisasi dari suatu masyarakat untuk menanggulangi kejahatan.
}

kesejahteraan masyarakat karena memberantas dan menanggulangi kejahatan perdagangan orang dengan mengandalkan upaya penal saja dipandang tidak cukup. Kebijakan kriminal perlu pula menyentuh ke akar masalah, yaitu penyebab munculnya perdagangan orang, di antaranya kemiskinan, kurangnya pendidikan dan keterampilan, kurangnya akses kesempatan dan informasi, serta nilai-nilai sosial budaya yang hanya mengutamakan terpenuhinya aspek ekonomi. ${ }^{34}$

Pembaharuan hukum pidana atau digunakan istilah rekonstruksi hukum pidana terhadap kejahatan perdagangan orang pada hakikatnya merupakan suatu upaya pembaharuan keseluruhan sistem hukum pidana terhadap pelarangan perdagangan orang. Barda Nawawi Arief $^{35}$ menjelaskan bahwa istilah restrukturisasi mengandung arti "penataan kembali". Dalam kaitannya dengan menata ulang bangunan sistem hukum pidana Indonesia, maka istilah restrukturisasi sangat dekat dengan "rekonstruksi", yaitu "membangun kembali" sistem hukum pidana nasional. Jadi kedua istilah itu sangat berkaitan erat dengan masalah law reform dan law development, khususnya berkaitan dengan "pembaharuan sistem hukum pidana" (penal sistem reform/development atau sering disebut secara singkat dengan istilah penal reform).

Dilihat dari sudut sistem hukum (legal system) yang terdiri dari legal substance, legal structure

\footnotetext{
${ }^{34}$ Ibid. Hal. 6.

${ }^{35}$ Barda Nawawi Arief. 2009. RUU KUHP Baru Sebuah Restrukturisasi/ Rekonstruksi Sistem Hukum Pidana Indonesia. Badan Penerbit Universitas Diponegoro. Semarang. Hal. 1.
} 
dan legal culture, maka pembaharuan sistem hukum pidana (penal system reform) tindak pidana perdagangan orang dapat meliputi ruang lingkup yang sangat luas, yaitu mencakup: ${ }^{36}$

a. Pembaharuan "substansi hukum pidana", yang meliputi pembaharuan hukum pidana materiel, hukum pidana formal, dan hukum pelaksanaan pidana atas kejahatan perdagangan orang.

b. Pembaharuan "struktur hukum pidana", yang meliputi antara lain pembaharuan atau penataan institusi/lembaga, sistem manajemen/tatalaksana dan mekanismenya serta sarana/ prasarana pendukung dari sistem penegakan hukum pidana (sistem peradilan pidana) terhadap kejahatan perdagangan orang; dan

c. Pembaharuan "budaya hukum pidana", yang meliputi antara lain masalah kesadaran hukum, perilaku hukum, pendidikan hukum dan ilmu hukum pidana, khususnya berkaitan dengan kejahatan atau tindak pidana perdagangan orang.

Pembaharuan sistem hukum pidana (penal sistem reform) yang diintegrasikan dengan kebijakan integral terhadap rekonstruksi pemberantasan tindak pidana perdagangan orang ini dipandang sesuai dengan Undang-Undang Nomor 17 Tahun 2007 tentang Rencana Pembangunan Jangka Panjang Nasional Tahun 20052025 , kondisi saat ini, yaitu dalam era reformasi upaya perwujudan

${ }^{36}$ Ibid. Hal. 2. sistem hukum nasional terus dilanjutkan mencakup beberapa hal:

a. Pembangunan substansi hukum, baik hukum tertulis maupun hukum tidak tertulis telah mempunyai mekanisme untuk membentuk hukum nasional yang lebih baik sesuai dengan kebutuhan pembangunan dan aspirasi masyarakat, yaitu berdasarkan Undang-Undang Nomor 10 Tahun 2004 tentang Pembentukan Peraturan Perundang-Undangan.

b. Penyempurnaan struktur hukum yang lebih efektif terus dilanjutkan.

c. Pelibatan seluruh komponen masyarakat yang mempunyai kesadaran hukum tinggi untuk mendukung pembentukan sistem hukum nasional yang dicitacitakan.

Pola umum rencana strategis pembangunan hukum itu dapat dijadikan landasan bagi penataan hukum nasional yang meletakkan pola pikir yang mendasari penyusunan sistem hukum nasional yang berintikan komponen materi hukum (legal substance), aparatur hukum (legal structure) dan budaya hukum (legal culture) serta didukung sarana dan prasarana yang memadai. Selain itu, pembangunan hukum haruslah juga memperbaharui sektorsektor lain seperti ilmu hukum dan ide-ide hukum melalui proses pendidikan dan pemikiran akademik. Dalam rangka inilah pembangunan hukum nasional harus didekati dengan mengubah sistem pendekatan yang sempit (legalistis) menjadi pendekatan yang lebih sistemik, holistik dan terpadu. Sistem pendekatan ini juga akan mendukung proses demokratisasi dan 
keterbukaan dan sekaligus akan menghasilkan masyarakat taat hukum.

Pembaharuan hukum dari masing-masing negara tidaklah sama, hal tersebut menyangkut dari latar belakang pembaharuan itu sendiri dan perkembangan masyarakat, yang tentunya tidak lepas dari nilai-nilai sosial budaya masing-masing bangsa yang sesuai dengan jelas jiwa bangsa (volkgeist) dari masing-masing Negara.

Jadi membangun dan merombak hukum Indonesia merupakan perpaduan dari pendekatan yang berorientasi pada nilai (value oriented approach), baik nilai-nilai kemanusiaan maupun nilai-nilai indentitas budaya dan nilai-nilai moral keagamaan yang hidup dalam masyarakat, pendekatan humanis, pendekatan kultural, dan pendekatan religius yang diintegrasikan ke dalam pendekatan rasional yang berorientasi pada kebijakan (policy oriented approach). Pentingnya produk hukum tertulis, yang bernama peraturan perundangundangan (legislation) yang mengusung spirit atau keinginan agar produk hukum tidak sekadar menjadi produk politik yang anti demokrasi. Undang-undang harus merekam dan mengakomodasikan kepentingan masyarakat, sehingga proses produksi hukum itu haruslah sedemokratis mungkin.

\subsection{Pembaharuan Perundang- Undangan Pemberantasan Kejahatan Perdagangan Orang melalui Agenda Prolegnas dan Prolegda 2010- 2014}

Mahfud $\mathrm{MD}^{37}$ menyatakan bahwa Prolegnas adalah instrumen perencanaan pembentukan undangundang yang disusun secara berencana, terpadu, dan sistematis yang memuat potret rencana hukum dalam periode tertentu disertai prosedur yang harus ditempuh dalam pembentukannya. Adapun, Prolegda mempunyai arti yang sama dengan Prolegnas tersebut, tetapi lingkup berlakunya hanyalah untuk daerah.

Abdul Latif dan Hasbi $\mathrm{Ali}^{38}$ menyatakan bahwa politik legislasi nasional (prolegnas-prolegda) merupakan upaya untuk mengkoordinasi berbagai program legislasi departemen dan lembaga nonpemerintah, nondepartemen dalam rangka mengarahkan agar pembentukan peraturan perundangundangan termasuk perda tersusun dalam satu sistem dan strategis yang sesuai dengan sasaran umum pembangunan nasional. Dari pengertian dan fungsi sistem prolegnas dan prolegda belum merupakan sistem yang terpadu yang akan menunjang sasaran umum pembangunan nasional karena:

a. Prolegnas dan prolegda belum disusun berdasarkan suatu perencanaan yang terpadu, sehingga tidak begitu tampak keterkaitan antara program yang satu dengan program yang lain.

b. Prolegnas dan prolegda masingmasing departemen dan lembaga nondepartemen menyusun daftar yang akan dikerjakan dan didasarkan pada tugas, wewenang dan prioritas masingmasing.

\footnotetext{
${ }^{37}$ Moh. Mahfud MD. 2010. Konstitusi dan Hukum dalam Kontroversi Isu. Rajawali Pers. Jakarta. Hal. 296.

${ }^{38}$ Abdul Latif dan Hasbi Ali. 2010. Politik Hukum. Sinar Grafika. Jakarta. Hal. 171.
} 
Prolegnas memuat daftar dan skala prioritas Program Legislasi Jangka Menengah dan Tahunan yang disusun secara berencana, terpadu dan sistematis oleh Dewan Perwakilan Rakyat bersama Pemerintah sesuai dengan perkembangan kebutuhan hukum masyarakat dalam mencapai tujuan negara pada tahap dan periode tertentu. ${ }^{39}$

Secara operasional Prolegnas memuat daftar rancangan undangundang yang disusun berdasarkan metode dan parameter tertentu serta dijiwai oleh visi dan misi pembangunan hukum nasional. Visi yang diemban dalam penyusunan Prolegnas adalah: ${ }^{40}$

Terwujudnya Negara hukum yang adil dan demokratis melalui pembangunan sistem hukum nasional dengan membentuk peraturan perundang-undangan yang aspiratif, berintikan keadilan dan kebenaran yang mengabdi pada kepentingan rakyat dan bangsa, serta tumpah darah Indonesia, memajukan kesejahteraan umum, mencerdaskan kehidupan bangsa dan ikut melaksanakan ketertiban dunia yang berdasarkan kemerdekaan, perdamaian abadi dan keadilan sosial berdasarkan Pancasila dan UUD 1945.

Untuk mencapai visi tersebut, Prolegnas disusun dengan misi: ${ }^{41}$

1. Mewujudkan materi hukum di segala bidang dalam rangka penggantian terhadap peraturan perundang-undangan warisan kolonial dan hukum nasional yang sudah tidak sesuai dengan

\footnotetext{
${ }^{39}$ Op.Cit. Moh. Mahfud MD. Hal. 296.

${ }^{40}$ Ibid. Hal. 296.

${ }^{41}$ Ibid. Hal. 296-297.
}

perkembangan masyarakat yang mengandung kepastian, keadilan dan kebenaran dengan memperhatikan nilai-nilai hukum yang hidup dalam masyarakat

2. Mewujudkan budaya hukum dalam masyarakat yang sadar hukum

3. Mewujudkan aparatur hukum yang berkualitas, profesional, bermoral dan berintegrasi tinggi; serta

4. Mewujudkan lembaga hukum yang kuat, terintegrasi dan berwibawa.

Dengan demikian, menjadi jelas bahwa Prolegnas dan Prolegda diadakan agar di dalam pembuatan undang-undang dan perda terbangun konsistensi isi secara berjenjang dengan Pancasila dan UUD Tahun 1945 melalui penyusunan rencana pembuatan undang-undang di tingkat nasional dan perda di tingkat daerah untuk periode lima tahun disertai prosedur dan mekanisme pembuatannya yang ketat. Prolegnas dan Prolegda yang dibuat untuk masa lima tahun ini dapat dipenggalpenggal ke dalam program tahunan sebagai prioritas pelaksanaan berdasar anggaran yang disediakan.

Berdasarkan kajian terhadap Daftar RUU Tahun 2010-2014 Prolegnas, ${ }^{42}$ revisi pemberantasan kejahatan perdagangan orang masih belum menjadi prioritas perhatian Pemerintah dan DPR untuk diagendakan perumusan dan pembahasannya. Sementara ini yang sudah diagendakan adalah RUU tentang Pemberantasan Perdagangan Anak, sementara RUU ini merupakan sebagian kecil persoalan di antara persoalan-persoalan

\footnotetext{
${ }^{42}$ Daftar Rancangan Undang-Undang (RUU) Tahun 2010-2014 Program Legislasi Nasional (Prolegnas).
} 
"gunung es" kejahatan perdagangan orang. Lagipula perumusan substansi RUU ini belum menjangkau kebijakan kriminal secara integral dalam kerangka upaya penanggulangan kejahatan perdagangan orang secara umum dan menyeluruh, terutama yang menekankan penanganan, pencegahan dan penanggulangan kejahatan perdagangan orang dengan menggunakan upaya nonpenalnya.

Namun usaha untuk memasukkan revisi pemberantasan kejahatan perdagangan belumlah pupus. Memang benar pembentukan undang-undang haruslah didasarkan pada Prolegnas, namun dengan alasan tertentu Prolegnas dapat disisipi dengan materi (RUU) baru, dalam hal ini RUU Pemberatasan/ Pelarangan Kejahatan Perdagangan Orang jika ada alasan-alasan yang kuat, yaitu karena: ${ }^{43}$

1. Ada putusan Mahkamah Konstitusi (MK) yang menyebabkan terjadinya kekosongan hukum yang harus segera diisi.

2. Ada Perppu yang mau atau tidak mau harus dibahas pada persidangan DPR berikutnya.

3. Ada perjanjian internasional yang harus diratifikasi dalam waktu singkat.

4. Keadaan luar biasa, keadaan konflik atau bencana alam.

5. Alasan keadaan tertentu lainnya yang memastikan adanya urgensi nasional atas suatu RUU baru yang dapat disetujui bersama oleh Badan Legislasi (Baleg) DPR dan Kemenhukham.

Keharusan adanya Prolegnas dan Prolegda dimaksudkan agar

${ }^{43}$ Ibid. Hal. 297. semua undang-undang dan Perda yang akan dibuat dapat dinilai lebih dulu kesesuaiannya dengan Pancasila dan UUD 1945 melalui perencanaan dan pembahasan yang matang. Di dalam Prolegnas dan Prolegda ini diatur pula mekanisme pembuatan undang-undang yang tidak boleh dilanggar dengan konsekuensi jika mekanisme itu dilanggar dapat dibatalkan melalui pengujian oleh lembaga yudisial melalui uji formal. Sedangkan jika pelanggaran terjadi dalam isi peraturan perundangundangan, maka pengujiannya dapat dilakukan melalui uji materiil. Dengan demikian, Prolegnas dan Prolegda menjadi isi (penuangan) Pancasila dan UUD 1945 di dalam undang-undang dan perda dengan dua fungsi, yaitu: ${ }^{44}$

1. Sebagai potret rencana isi hukum untuk mencapai tujuan negara yang sesuai dengan Pancasila, UUD 1945, dan sistem hukum nasional selama lima tahun; disini rencana isi hukum dapat dibicarakan lebih dulu agar sesuai dengan Pancasila dan kaidah-kaidah penuntun hokumnya. Kesalahan isi peraturan perundang-undangan, yaitu dalam arti Prolegnas yang pertama ini dapat dibatalkan dengan pengujian yudisial (judicial review) melalui uji materiil.

2. Sebagai mekanisme atau prosedur pembuatan peraturan perundang-undangan agar apa yang telah ditetapkan sebagai rencana dapat dilaksanakan dengan prosedur dan mekanisme yang benar. Kesalahan dalam prosedur pembentukan peraturan perundang-undangan dalam arti

\footnotetext{
${ }^{44}$ Ibid. Hal. 297-298.
} 
Prolegnas yang kedua ini dapat dibatalkan dengan pengujian yudisial (judicial review) melalui uji formal.

Jika Prolegnas diletakkan di dalam alur pikir politik pembangunan hukum nasional dapat diurut secara singkat sebagai berikut: ${ }^{45}$

1. Hukum nasional harus dibuat sesuai dengan cita-cita bangsa (yang ada di hati sanubari rakyat) yakni masyarakat adil dan makmur berdasar Pancasila.

2. Hukum nasional harus dirancang untuk mencapai tahap tertentu dari tujuan negara sebagaimana tertuang di dalam Pembukaan UUD 1945, yaitu: (1) melindungi segenap bangsa dan seluruh tumpah darah Indonesia; (2) mencerdaskan kehidupan bangsa; (3) memajukan kesejahteraan umum; (4) ikut melaksanakan ketertiban dunia.

3. Hukum nasional harus bersumber dari, dan menuju, Pancasila citacita bangsa dan tujuan Negara. Dari sini kemudian lahir kaidahkaidah penuntun hukum, yaitu: (1) hukum nasional harus menjamin integrasi bangsa dan Negara, baik teritori maupun ideologi; (2) hukum nasional harus mengintegrasikan prinsip demokrasi dan nomokrasi; (3) hukum nasional harus berorientasi pada pembangunan keadilan sosial; (4) hukum nasional harus menjamin hidupnya toleransi beragama yang berkeadaban.

4. Hukum nasional harus menuangkan asas-asas atau norma dasar yang tertuang di dalam UUD

\footnotetext{
${ }^{45}$ Ibid. Hal. 300.
}

5. Hukum nasional harus dibuat berdasar Prolegnas yang memuat potret atau rencana isi hukum dalam periode tertentu serta prosedur-prosedurnya. Prolegnas merupakan gambar rencana pencapaian tujuan Negara dalam tahap tertentu yang harus dibuat untuk menderivasi UUD ke dalam peraturan perundangundangan.

6. Judicial review dapat dilakukan oleh MK untuk menjamin konsistensi isi undang-undang terhadap UUD serta menjamin ketepatan prosedur sesuai dengan Prolegnas.

7. Judicial review dapat dilakukan MA untuk menjamin konsistensi isi peraturan perundangundangan dibawah undangundang terhadap peraturan perundang-undangan yang lebih tinggi, sekaligus menguji ketepatan prosedur pembentukannya.

8. Prolegda yang memuat potret isi dan prosedur perda untuk waktu tertentu guna menjamin konsistensi isi dengan peraturan perundang-undangan yang lebih tinggi serta untuk menjamin ketepatan prosedur.

Alur pikir tersebut dapat disingkat dengan pernyataan bahwa untuk memaksimalkan peran Prolegnas dan Prolegda dalam politik hukum nasional harus dibuat dengan jaminan akan ketepatan isi dan ketepatan prosedur yang harus didasarkan pada kaidah-kaidah penuntun hukum dan UUD 1945 untuk mencapai tujuan negara dalam tahap atau periode tertentu. Jika salah dalam pemuatan isi dan prosedur pembuatannya dapat diuji oleh lembaga yudisial melalui judicial review. Perlu ditekankan disini 
menurut Pasal 17 ayat (1) UndangUndang Nomor 10 Tahun 2004, bahwa setiap rancangan undangundang, baik yang berasal dari DPR maupun yang berasal dari Pemerintah harus disusun di dalam Prolegnas. $^{46}$

\section{SIMPULAN}

1. Politik hukum pembangunan hukum pemberantasan kejahatan perdagangan orang di era globalisasi melalui pembaharuan sistem hukum pidana (penal system reform) kejahatan perdagangan orang meliputi ruang lingkup yang sangat luas, yaitu mencakup pembaharuan "substansi hukum pidana", yang meliputi pembaharuan hukum pidana materiel, hukum pidana formal, dan hukum pelaksanaan pidana atas kejahatan perdagangan orang. Pembaharuan "struktur hukum pidana", yang meliputi antara lain pembaharuan atau penataan lembaga, sistem manajemen dan mekanismenya serta sarana/ prasarana pendukung dari sistem penegakan hukum pidana (sistem peradilan pidana) terhadap kejahatan perdagangan orang; dan pembaharuan "budaya hukum pidana", yang meliputi antara lain masalah kesadaran hukum, perilaku hukum, pendidikan hukum dan ilmu hukum pidana, khususnya berkaitan dengan kejahatan atau tindak pidana perdagangan orang.

2. Usaha untuk memasukkan revisi pemberantasan kejahatan perdagangan dengan pendekatan kebijakan kriminal secara integral dalam agenda Prolegnas dan Prolegda 2010-2014 belumlah pupus, meskipun sekarang ini belum diagendakan oleh DPR RI dan Pemerintah RI. Prolegnas dapat disisipi dengan materi RUU Pemberantasan Kejahatan Perdagangan Orang jika ada alasan-alasan yang kuat, yaitu karena adanya putusan Mahkamah Konstitusi (MK) yang menyebabkan terjadinya kekosongan hukum Pemberantasan Kejahatan Perdagangan Orang yang harus segera diisi. Ada perjanjian internasional yang harus diratifikasi dalam waktu singkat. Alasan keadaan tertentu lainnya yang memastikan adanya urgensi nasional atas suatu RUU baru yang dapat disetujui bersama oleh Badan Legislasi (Baleg) DPR dan Kemenhukham RI.

\section{DAFTAR PUSTAKA}

Satya Arinanto dan Ninuk Triyanti (editor), 2009. Memahami Hukum: Dari Konstruksi sampai Implementasi. Rajawali. Jakarta.

Arief, Barda Nawawi. 1994. Beberapa Aspek Pengembangan Ilmu Hukum Pidana (Menyongsong Generasi Baru Hukum Pidana Indonesia) Pidato Pengukuhan sebagai Guru Besar Ilmu Hukum di hadapan Rapat Senat Terbuka Undip, Semarang 25 Juni 1994. 2005. Beberapa Aspek Kebijakan Penegakan dan Pengembangan Hukum

${ }^{46}$ Ibid. Hal. 302. 
Pidana. Citra Aditya Bakti. Bandung.

$\begin{array}{lr}\text { Sebuah } & \text { Restrukturisasi/ } \\ \text { Rekonstruksi Sistem Hukum } \\ \text { Pidana Indonesia. Badan } \\ \text { Penerbit Universitas } \\ \text { Diponegoro. Semarang. }\end{array}$

Atmasasmita, Romli. 2003. Pengantar Hukum Pidana Internasional. Refika Aditama. Bandung. 2010. Hukum Pidana Internasional: Dalam Kerangka Perdamaian dan Keamanan Internasional. Fikahati Aneska. Jakarta.

Emmy L.S. 2010. Makalah "Implementasi UU PTPPO bagi Anak Korban Perdagangan," dalam Jurnal Perempuan: Untuk pencerahan dan kesetaraan 68. Trafficking dan Kebijakan. Yayasan Jurnal Perempuan. Jakarta.

Farhana. 2010. Aspek Hukum Perdagangan Orang di Indonesia. Sinar Grafika. Jakarta.

Hartono, C.F.G. Sunaryati. 1991. Politik Hukum Manuju Satu Sistem Hukum Nasional. Alumni. Bandung.

Lapian, L.M. Gandhi. 2010. Convention Watch UI: Kiprah Penanggulangan Trafiking di Sulawesi Utara. Dalam Trafiking Perempuan dan Anak: Penanggulangan Komprehensif Studi Kasus: Sulawesi Utara. Yayasan Obor Indonesia.

Mahfud MD, Moh. 2010. Konstitusi dan Hukum dalam Kontroversi Isu. Rajawali Pers. Jakarta.
Abdul Latif dan Hasbi Ali. 2010. Politik Hukum. Sinar Grafika. Jakarta. 2010. Membangun Politik Hukum, Menegakkan Konstitusi. Rajawali Pers. Jakarta.

----------. 2010. Politik Hukum di Indonesia. Rajawali Pers. Jakarta.

Muladi. 2002. Demokratisasi, Hak Asasi Manusia, dan Reformasi Hukum di Indonesia. The Habibie Center. Jakarta.

Parthiana, I Wayan. 2004. Hukum Pidana Internasional dan Ekstradisi. Yrama Widya. Bandung.

Permana, Is. Heru. 2007. Politik Kriminal. Universitas Atma Jaya. Yogyakarta.

Rahardjo, Satjipto. 2009. Membangun dan Merombak Hukum Indonesia: Sebuah Pendekatan Lintas Disiplin. Genta Publishing. Yogyakarta.

Subono, Nur Iman. 2010. "Trafficking in Human Beings dalam Angka dan Perdebatan" dalam Jurnal Perempuan: Untuk pencerahan dan kesetaraan 68. Trafficking dan Kebijakan. Yayasan Jurnal Perempuan.

Konvensi PBB Anti Kejahatan Transnasional Terorganisasi (2000).

Undang-Undang Republik Indonesia

Nomor 17 Tahun 2007

tentang Rencana

Pembangunan Jangka

Panjang Nasional Tahun $2005-2025$.

http://www.menegpp.go.id/index.php ?option=com_content\&view 
$=$ article $\&$ id $=282$ :rakornas-

evaluasi-gugus-tugas-

pencegahan-dan-

penanganan-tppo-

2010\&catid=36:press-

release \&Itemid $=87$ diunduh

pada tanggal 17 Mei 2011

pukul 20.31 WIB.

http://www.menegpp.go.id/index.php

?option=com_content\&view

=article\&id=147:jameela-a-

sang-presiden \&catid $=38$

artikel-perempuan\&Itemid

$=114$ diunduh pada tanggal

17 Mei 2011 pukul 20.33

WIB. 